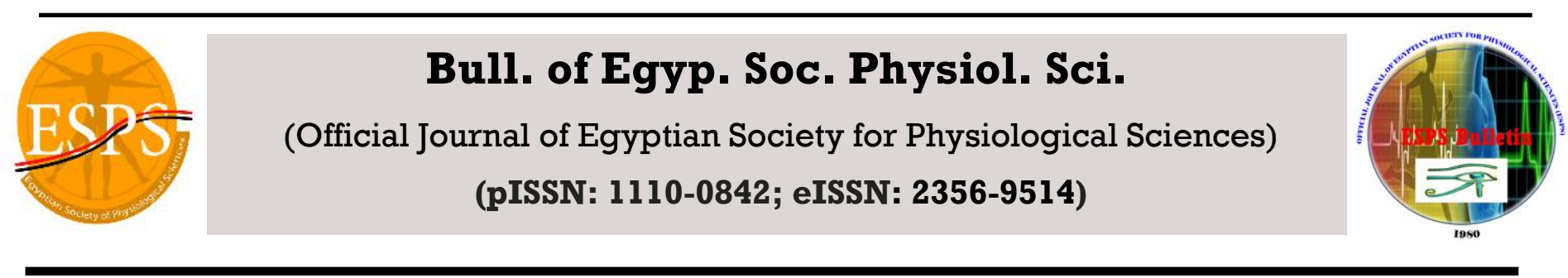

\title{
Effect of L-Carnitine on Insulin Sensitivity and Responsiveness in Skeletal Muscle, Adipose tissue and Hepatic tissues
}

\author{
Mohammed Adel \\ Department of Medical Physiology, Faculty of Medicine, Mansoura University, Egypt.
}

Received: 21 Dec 2014

Accepted: 25 May 2015

Available online: 5 July 2015

\section{Keywords}

- L-Carnitine

- Insulin

Sensitivity

- Insulin

Responsiveness

\begin{abstract}
Background and objectives: L-carnitine (LC) is a non-protein amino acid includes both diet and endogenous synthesis. There are no studies on the effect of LC on glucose uptake and net glucose output in muscle and hepatic tissues. So, the aim of the present work is to study the metabolic aspects of LC and to study some mechanisms that may be of help in treatment of insulin resistance. Methods: Twenty four male rats were divided into two main groups, twelve rats per each group. In vivo group was divided into control one and L-Carnitine - treated one, It was given in the dose of $3 \mathrm{gm}$ carnitine $/ \mathrm{kg}$ once every day orally for 4 weeks where fasting serum glucose and plasma free fatty acids (FFA) were measured. In vitro group included experiments on epididymal fat pad (EFP), hemidiaphragm and liver. Results: LC caused a highly significant decrease in fasting plasma FFA level $(4.9 \pm 1.5 \mathrm{mg} / \mathrm{dl})$. However, it caused a significant increase in insulin-stimulated glucose uptake by EFP in the presence of supraminimal and supramaximal insulin concentrations $(2.5 \pm 0.8$ and 3.4 \pm 0.4$)(\mathrm{mg} / \mathrm{gm}$ wet tissue /hour) and also by hemidiaphragm $(4.9 \pm 0.3$ and $6 \pm 0.97)(\mathrm{mg} / \mathrm{gm}$ wet tissue /hour). Also, it increased net glucose output by liver slices in the presence of both insulin concentrations $(-4.9 \pm 1.1$ and $-4 \pm$ 1.42) (mg/ gm wet tissue /hour). It decreased FFA release from EFP in the presence of both insulin concentrations $(0.5 \pm 0.21$ and $0.4 \pm 0.2)(\mathrm{mg} / \mathrm{gm}$ wet tissue /hour $)$, hemidiaphragm $(0.5 \pm 0.1$ and $0.5 \pm 0.16)(\mathrm{mg} / \mathrm{gm}$ wet tissue /hour) and liver slices $(0.58 \pm 0.19$ and $0.63 \pm 0.27)$ (mg/ gm wet tissue /hour). Conclusion: LC increased plasma FFA level. It potentiated the effect of insulin on glucose uptake in EFP and hemidiaphragm. It decreased hepatic insulin sensitivity and responsivity and enhanced the suppressive effect of insulin on FFA release from different peripheral tissues.
\end{abstract}

Corresponding author: Mohamed Adel, Department of Medical Physiology, Mansoura Faculty of Medicine, Mansoura, Egypt. phone: +21222218973; email: made17744@yahoo.com 


\section{INTRODUCTION}

L-carnitine (LC) belongs to a group of food factors known as non-nutrient supplements. It is synthesized in the body from the lysine and methionine ${ }^{[1]}$. Several clinical conditions of LC deficiency have been described, including the genetic deficiency of LC, hemodialysis, muscular and liver disorders, kidney and cardiovascular diseases and diabetes mellitus ${ }^{[2]}$.

In presence of L-carnitine deficiency, a common feature appears to be the increased serum concentration of triacylglycerol ${ }^{[3-6]}$. Therefore, a relevant aspect of the L-carnitine supplementation is a lipid-lowering effect observed in the experimental animals ${ }^{[7-12]}$ and humans ${ }^{[13-17]}$.

On the other hand, diabetes promotes LC deficiency $[18,19]$ and increased blood triacylglycerol. However, studies investigating the effect of LC supplementation on the blood levels of triacylglycerol in type 1 diabetes are absent. So, the aim of the present work is to clarify:

1) The effect of LC on serum glucose level and plasma FFA level in rats 2) the effect of LC on basal and insulin-stimulated glucose uptake by different tissues 3) the effect of LC on FFA release in presence or absence of insulin in such tissues

\section{MATERIALS AND METHODS}

\section{Experimental animals}

Twenty four healthy male Sprague Dawley rats, $80 \pm 5$ days old with average weight of $250 \pm$ 50 grams old were used in the study. They were obtained from Medical Experimental Research Center of Mansoura University, Egypt. The experimental protocol was approved by the Institutional Animal Ethics Committee of Mansura University. Rats were housed in policarbon cages and were exposed to a $12 \mathrm{~h}$ light-dark cycle at a room temperature of $21-24^{\circ} \mathrm{C}$ and $50-60 \%$ relative humidity.

The animals were studied in the fasting state, and these tissues were obtained:

- Adipose Tissue: was obtained from epididymal adipose tissue

- Skeletal Muscle: was obtained from hemidiaphragm

- Liver Slices: were obtained from right lobe of the liver

These tissues were obtained from the rats after overnight fast. Rats were anaethetized with an intraperitoneal injection of $50 \mathrm{mg}$ per $\mathrm{kg}$ body weight sodium thiopental. The skin over the abdomen was removed. The lower abdominal cavity was widely exposed, then displacing the testes into the abdominal cavity by gentle pressure over the scrotum. Each testicle was elevated with the forceps until the main spermatic blood vessels could be seen together with the pampiniform plexus of veins. The distal part of the epididymal fat pads, distal to the entrance of the blood vessels, was dissected from right and left sides. Thin liver slices were obtained using sharp scalpel. Diaphragm was dissected carefully and divided into two halves excluding the central tendon. These tissues were washed in Krebs Ringer Bicarbonate Buffered Solution (KRBBS), dry by filter paper then placed immediately in the incubation medium (Krebs and Henseleit, 1950).

\section{Incubation Procedures}

$3 \mathrm{ml}$ of the incubation medium was placed in each dry and clean bottle and the weight of each with its contents was determined. Different tissues (epidydimal fat pad, hemidiaphragm, liver slices) 
were placed in the weighed bottles. The bottles were reweighed to determine the weight of the tissues. For each set of experiments, $3 \mathrm{ml}$ of the incubation medium was placed in a given incubation bottle without added tissue and is considered as control for changes in level of glucose and free fatty acids (FFA).Insulin and/or LC was/or were added to incubation medium. The supraminimal concentration of insulin was (100 $\mu \mathrm{U}$ per ml) and the supramaximal concentration was $(10 \mathrm{mU}$ per $\mathrm{ml})$. The incubation bottles were gassed again with carbogen for 30 seconds each. Then they were shut of with tightly fitting rubber stopper and placed for one hour in the metabolic shaker at $37^{\circ} \mathrm{C}$ with a shaking rate of 100 r.p.m. After incubation was off, the bottles were taken outside the shaker, cooled under running tap water, and kept inverted while still closed to include the condensed vapour on the upper wall of the flasks into the medium. The covers of the bottles were opened, the incubated tissues were removed and then the solution was taken from medium for assay.

\section{Chemicals and Drugs Used}

- LC was obtained from (MEPACO Egypt). It was given in the dose of $3 \mathrm{gm}$ carnitine $/ \mathrm{kg}$ once every day orally for 4 weeks (20)

- Insulin: actrapid insulin, in the form of ampoule containing $10 \mathrm{ml}$ in a concentration of $100 \mathrm{IU}$ per $\mathrm{ml}$

\section{Experimental Groups}

\section{In Vivo Experiments}

- Control group containing six rats

-L-Carnitine -treated group containing six rats. The rats received L-carnitine in the dose of $3 \mathrm{gm}$ carnitine / $\mathrm{kg}$ once every day orally for 4 weeks [30]

After one week, the rats were sacrificed

- Blood samples were taken from the fasting rats through intracardiac blood sampling method for determination of serum glucose and plasma free fatty acids (FFA) level

\section{In Vitro Experiments}

\section{A. Experiments on Epididymal Fat Pad (EFP)}

1. Studying glucose uptake

2. Studying glucose uptake in the presence of LC supplementation $2 \mathrm{mM}$ in $5 \mathrm{mg} / \mathrm{mL}$ concentration

3. Studying glucose uptake in the presence of supraminimal concentration of insulin (100 $\mu \mathrm{U}$ per $\mathrm{ml})$.

4. Studying glucose uptake in the presence of LC and supraminimal concentration of insulin (100 $\mu \mathrm{U}$ per ml)

5. Studying glucose uptake in the presence of supramaximal concentration of insulin $(10 \mathrm{mU}$ per $\mathrm{ml}$ )

6. Studying glucose uptake in the presence of LC and supramaximal concentration of insulin(10 mU per ml)

\section{B. Experiments on Hemidiaphragm}

1. Studying glucose uptake (Control group)

2. Studying glucose uptake in the presence of LC

3. Studying glucose uptake and free fatty acids (FFA) release in the presence of supraminimal concentration of insulin $(100 \mu \mathrm{U}$ per ml)

4. Studying glucose uptake in the presence of LC and supraminimal concentration of insulin $(100 \mu \mathrm{U}$ per ml) 
5. Studying glucose uptake and free fatty acids (FFA) release in the presence of supramaximal concentration of insulin (10 $\mathrm{mU}$ per $\mathrm{ml}$ )

6. Studying glucose uptake in the presence of LC and supramaximal concentration of insulin $(10 \mathrm{mU}$ per $\mathrm{ml})$

\section{Experiments on liver slices}

1. Studying net glucose uptake (Control group)

2. Studying net glucose uptake in the presence of LC

3. Studying net glucose uptake the presence of supraminimal concentration of insulin (100 $\mu \mathrm{U}$ per ml)

4. Studying net glucose uptake in the presence of LC and supraminimal concentration of insulin $(100 \mu \mathrm{U}$ per ml $)$

5. Studying net glucose uptake in the presence of supramaximal concentration of insulin (10 $\mathrm{mU}$ per $\mathrm{ml}$ )

6. Studying net glucose uptake in the presence of LC and supramaximal concentration of insulin(10 $\mathrm{mU}$ per $\mathrm{ml})$

\section{Incubation Medium}

The incubation medium employed was Krebs Ringer Bicarbonate Buffered Solution (KRBBS).

\section{Measured parameters}

Serum glucose level, plasma FFA level, tissue specific glucose uptake and FFA release

\section{Tissues Glucose Uptake}

It was calculated as $\mathrm{mg}$ per gm wet tissue weight per hour. The glucose uptake was calculated using the following equation:

Glucose uptake $=\frac{\mathrm{M} \times V \times 1000}{\mathrm{~N} \times 100} \mathrm{mg}$ per gm wet tissue per hour

Where:
$\mathbf{N}=$ Net weight of tissue in $\mathrm{Gm}$

$\mathbf{V}=$ volume in $\mathrm{ml}$ of the incubation medium in the flask $(3 \mathrm{ml})$

$\mathbf{M}=$ difference in the concentration of glucose per $100 \mathrm{ml}$ of the medium between the control and the tissue bottles

\section{Determination of Free Fatty Acids (FFA)}

The principal based on the colorimeteric method already described for chloroform solutions of fatty acids.

The method adapted in the present work is that of Dunucomb (1964). The principal based on the colorimeteric method already described for chloroform solutions of fatty acids.

\section{Statistical analysis:}

Values were expressed in the form of mean $(+/-)$ SD which are done by using excel program for figures and SPSS (SPSS, Sigma Plot Software, Inc, Chicago, IL) program statistical package for social science version 16 . To test the normality of data distribution K-S (Kolmogorovo-Smirnov) test was done only significant data revealed to be nonparametric.

N.B: all tested data revealed to be parametric

The description of data was done in the form of mean (+/-) SD for quantitative data and frequency $\&$ proportion for qualitative data. The analysis of the data was done to test statistical significant difference between groups. For quantitative data student t-test was used to compare between groups. Paired sample t-test to compare one group at different time.

To test the association between variables correlation co-effeciency test was done.

N.B: $P$ is significant if lower than or $=0.05$ at confidence interval $95 \%$. The level of significance as the follow: $\mathrm{P}$ higher than 0.05 non significant, $\mathrm{P}$ 
lower than 0.05 significant, $\mathrm{P}$ lower than 0.01 highly significant, $\mathrm{P}$ lower than 0.001 very highly significant

\section{RESULTS}

Results are illustrated in tables 1,2 and 3 and figures 1,2 and 3

Table 1: Effect of L-Carnitine on fasting serum glucose level (mg/dl) and Fasting Plasma Free Fatty Acids (FFA) $(\mathrm{mg} / \mathrm{dl})$ level

\begin{tabular}{|c|c|c|c|}
\hline & & Control group & $\begin{array}{c}\text { L-Carnitine -treated } \\
\text { group }\end{array}$ \\
\hline \multirow{3}{*}{$\begin{array}{l}\text { Fasting Serum Glucose Level } \\
(\mathrm{mg} / \mathrm{dl})\end{array}$} & Mean & 99 & 97 \\
\hline & $\pm \mathrm{SD}$ & \pm 5.21 & \pm 4.42 \\
\hline & $\mathbf{P}$ & & NS \\
\hline \multirow{3}{*}{$\begin{array}{l}\text { Fasting Plasma Free Fatty } \\
\text { Acids (FFA) (mg/dl) level }\end{array}$} & Mean & 22 & 4.92 \\
\hline & \pm SD & \pm 2.05 & \pm 1.54 \\
\hline & $\mathbf{P}$ & & 0.000 \\
\hline
\end{tabular}

P: as compared with control group. NS: denotes non significant

Table 2: Effect of LC on glucose uptake (mg/gm wet tissue/h.) by epididymal fat pad, hemidiaphragm and net glucose uptake by liver slices in basal conditions and in the presence of supraminimal (100 $\mu \mathrm{U}$ per ml) and supramaximal concentrations of insulin (10 $\mathrm{mU}$ per $\mathrm{ml})$

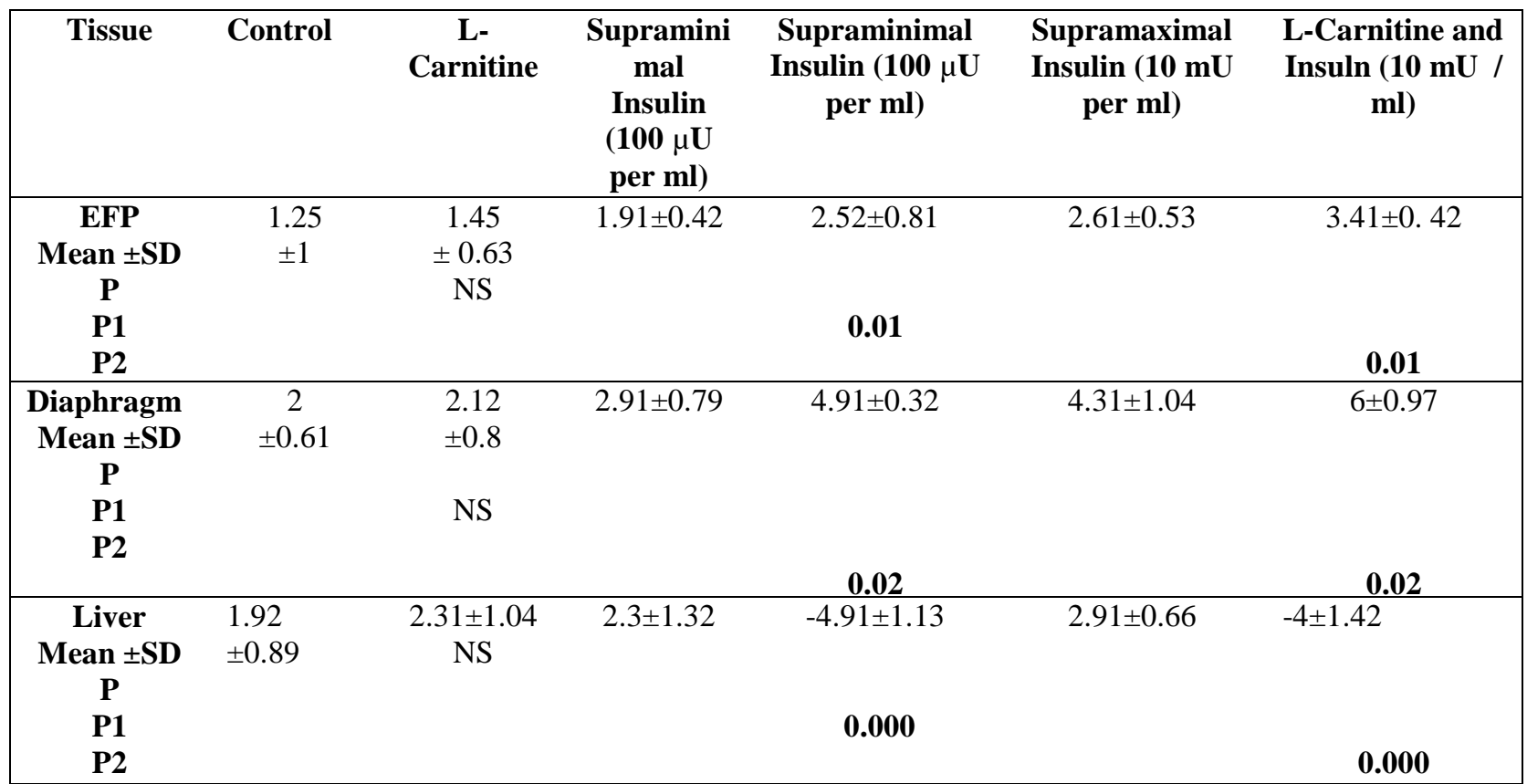

The results are Mean \pm SD. P: as compared with control. P1: as compared with supraminimal insulin, P2: as compared with supramaximal insulin.NS: denotes non significant 
Table 4: Effect of LC on free fatty acids (FFA) release (mg/gm wet tissue/h.) from epididymal fat pad, hemidiaphragm and liver slices in basal conditions and in the presence of supraminimal (100 $\mu \mathrm{U}$ per ml) and supramaximal concentrations of insulin (10 $\mathrm{mU}$ per $\mathrm{ml})$

\begin{tabular}{|c|c|c|c|c|c|c|}
\hline Tissue & Control & $\begin{array}{c}\text { L- } \\
\text { Carnitine }\end{array}$ & $\begin{array}{l}\text { Supraminim } \\
\text { al } \\
\text { Insulin (100 } \\
\mu \mathrm{U} \text { per } \mathbf{m l})\end{array}$ & $\begin{array}{c}\text { L-Carnitine } \\
\text { Supraminimal } \\
\text { Insulin (100 } \\
\mu \mathrm{U} \text { per } \mathbf{m l})\end{array}$ & $\begin{array}{l}\text { Supramaxima } \\
\text { I Insulin }(10 \\
\text { mU per } \mathbf{m l})\end{array}$ & $\begin{array}{c}\text { L-Carnitine and } \\
\text { Supramaximal } \\
\text { Insulin }(\mathbf{1 0} \mathrm{mU} \text { per } \\
\text { ml })\end{array}$ \\
\hline $\begin{array}{c}\text { EFP } \\
\text { Mean } \pm \text { SD } \\
\text { P } \\
\text { P1 } \\
\text { P2 } \\
\end{array}$ & $\begin{array}{c}1.31 \pm \\
0.59\end{array}$ & $\begin{array}{l}1.12 \pm \\
0.43 \\
\mathrm{NS}\end{array}$ & $0.71 \pm 0.21$ & $0.53 \pm 0.21$ & $0.53 \pm 0.21$ & $0.41 \pm 0.23$ \\
\hline $\begin{array}{l}\text { Diaphra- } \\
\text { gm } \\
\text { Mean } \pm \text { SD } \\
\text { P } \\
\text { P1 } \\
\text { P2 }\end{array}$ & $\begin{array}{c}1.22 \\
\pm 0.39\end{array}$ & $\begin{array}{c}1 \\
\pm 0.14 \\
\text { NS }\end{array}$ & $0.71 \pm 0.23$ & $0.52 \pm 0.13$ & $0.61 \pm 0.24$ & $0.51 \pm 0.16$ \\
\hline $\begin{array}{c}\text { Liver } \\
\text { Mean } \pm \text { SD } \\
\text { P } \\
\text { P1 } \\
\text { P2 }\end{array}$ & $\begin{array}{c}1 \\
\pm 0.26\end{array}$ & $\begin{array}{c}0.92 \\
\pm 0.24 \\
\text { NS }\end{array}$ & $0.71 \pm 0.14$ & $0.58 \pm 0.19$ & $0.72 \pm 0.19$ & $0.63 \pm 0.27$ \\
\hline
\end{tabular}

P: as compared with control P1: as compared with supraminimal insulin P2: as compared with supramaximal insulin

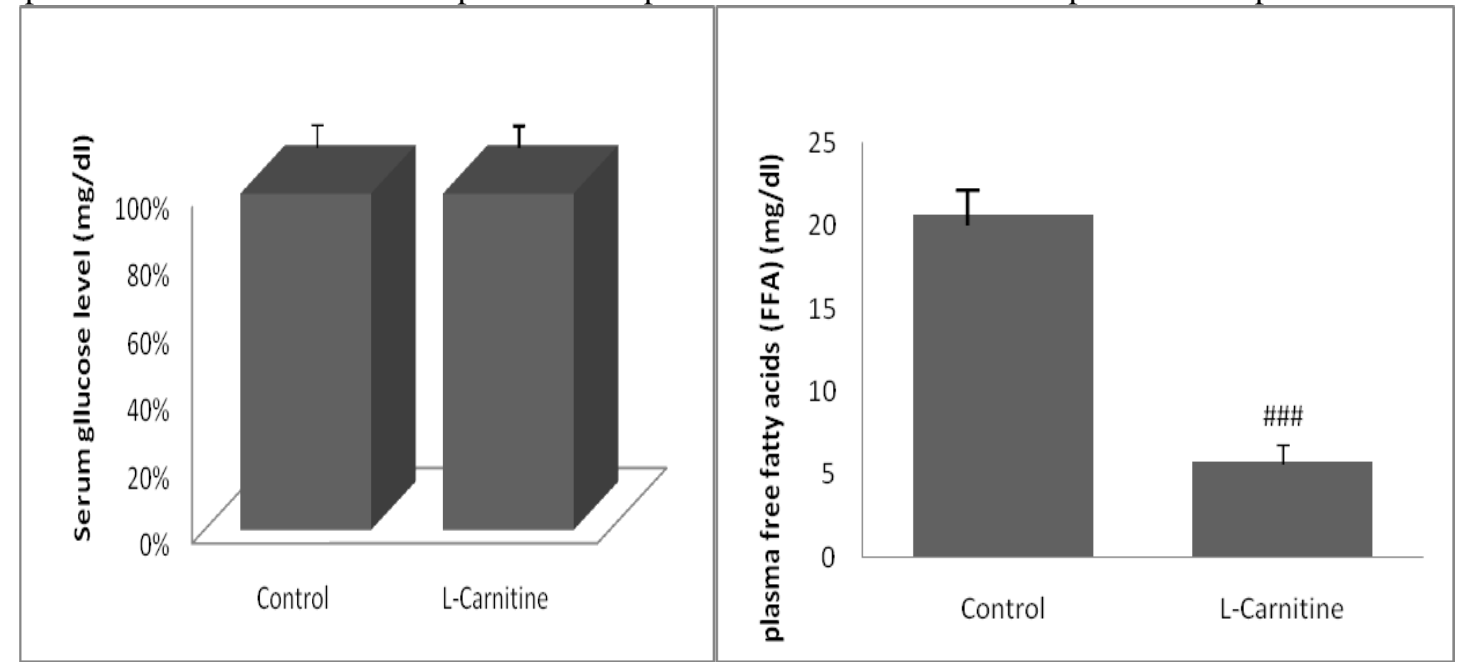

Fig. 1. Effect of L-Carnitine on fasting serum glucose level (mg/dl) (a) and fasting plasma free fatty acids (FFA) (mg/dl) (b) \#\#\# denotes that $\mathrm{P}=0.000$ 

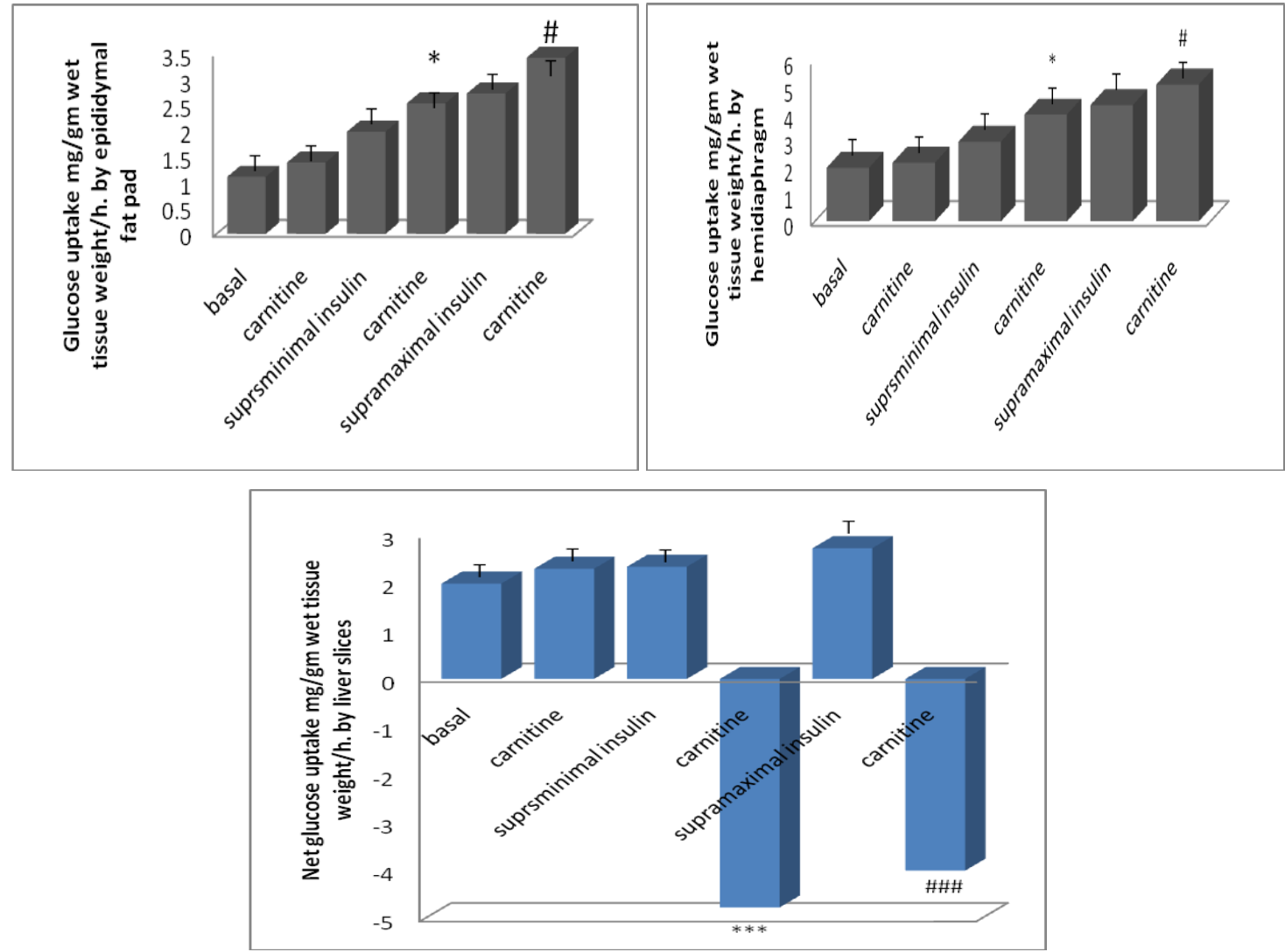

Fig. 2. Effect of L-Carnitine on glucose uptake $(\mathrm{mg} / \mathrm{gm}$ wet tissue/h.) by epididymal fat pad, hemidiaphragm and net glucose uptake by liver slices in basal conditions and in the presence of supraminimal $(100 \mu \mathrm{U}$ per ml) and supramaximal concentrations of insulin $(10 \mathrm{mU}$ per $\mathrm{ml}) *$ : Significant as compared with supraminimal insulin \#: Significant as compared with supramaximal insulin

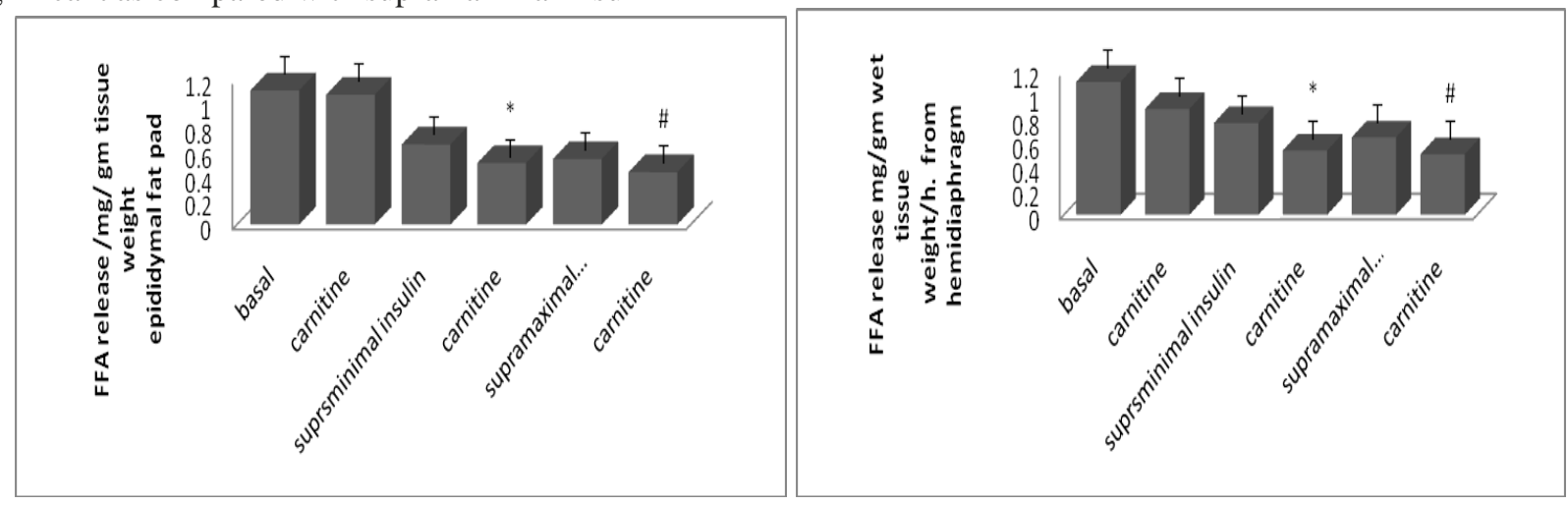

Fig. 3. Effect of L-Carnitine on free fatty acids (FFA) release (mg/gm wet tissue/h.) from epididymal fat Pad, hemidiaphragm and liver slices in basal conditions and in the presence of supraminimal $(100 \mu \mathrm{U}$ per ml) and supramaximal concentrations of insulin $(10 \mathrm{mU}$ per $\mathrm{ml}) *$ : Significant as compared with supraminimal insulin, \#: Significant as compared with supramaximal insulin 


\section{DISCUSSION}

LC acts as a cofactor in beta-oxidation by facilitating long chain FA entrance into mitochondria in the form of LC esters (carnitinepalmitoyl transferase system CPT-I and II) and the exit of acetyl groups from mitochondria to the cytosol (carnitine acyl transferase system) [21,22]. A reduction in FA transportation to mitochondria facilitates triglyceride accumulation in the cytosol, which is related with the pathogenesis of insulin resistance (IR). Although the mechanisms by which FA dysregulation leads to insulin resistance are not well understood, the following pathways could be involved: a) accumulation of diacylglycerol and acyl-CoA, which could cause defects in insulin signalling, b) the inhibition of GLUT-4 translocation by long chain acyl-CoA, c) non metabolised FA accumulation in mitochondria, which could cause mitochondrial stress and IR ${ }^{[23,24]}$. These mechanisms may explain why LC, being a conditionally essential nutrient involved in bidirectional transportation of acyl-CoA in mitochondria, could reduce lipid overload and improve insulin-sensitivity.

Although LC is known to play a beneficial role in diabetes, however, there are no studies on the effect of LC on glucose uptake and net glucose output in muscle and hepatic tissues. So, the aim of the present work is to clarify:

1) The effect of LC on serum glucose level and plasma FFA level in rats 2) the effect of LC on basal and insulin-stimulated glucose uptake by different tissues 3 ) the effect of LC on FFA release in presence or absence of insulin in such tissues

In this study, LC non-significantly decreased serum glucose level. This is in agreement with the work of Bazotte and Lopes-Bertolini ${ }^{[25]}$ who found a decrease in serum glucose level following LC administration.

In this study, LC has no significant effect on basal glucose uptake by epididymal adipose tissue but significantly increased glucose uptake in the presence of both supraminimal and supramaximal insulin concentrations suggesting that LC acts synergistically with insulin. This is in agreement with the work of Patel et al. ${ }^{[26]}$ who demonstrated an increase in insulin-stimulated glucose uptake in isolated epididymal adipose tissue in a dose dependent manner.

The results of the present study demonstrated that LC has no significant change in basal net glucose uptake by the liver slices. However, Lcarnitine increases net glucose production in the presence of insulin suggesting antagonism of insulin action.

Insulin inhibits gluconeogenesis, through the activation of the insulin receptor (IR). It acts predominantly by suppressing the expression of the genes for the key gluconeogenic enzymes phosphor-enol-pyruvate-carboxykinase (PEPCK) and glucose-6-phosphatase (G6Pase) ${ }^{[27,28]}$.

Also, in this study, LC caused a highly significant decrease in plasma FFAs level. This is in agreement with the work of Bieber ${ }^{[29]}$. This effect could be explained by the effect of LC on improvement of fatty acid oxidation.

We have investigated the direct effects of LC on FFAs release from epididymal fat pad in vitro. It was observed that LC caused a non-significant decrease in FFAs release. Addition of supraminimal and supramaximal concentrations of insulin caused a significant decrease in FFAs release. Addition of LC to the incubation medium 
with insulin in both concentrations caused a more significant decrease in FFAs release.

We have also investigated the effects of LC on FFAs release from hemidiaphragm. It caused a non-significant decrease in free fatty acids (FFAs) release. However, addition of LC with insulin in both concentrations caused a more significant decrease in FFAs release suggesting potentiation of insulin action in inhibiting lipolysis.

In the present study, we have investigated the effects of LC on FFAs release from liver slices. It caused a non-significant decrease in free fatty acids (FFAs) release. Addition of supraminimal and supramaximal concentrations of insulin to the incubation medium caused a significant decrease in FFAs release. Addition of LC with insulin in both concentrations to the incubation medium caused a more significant decrease in FFAs release.

The data in this work support a direct role for LC in enhancing insulin-inhibited FFAs release in isolated epididymal adipose tissue, hemidiaphragm and liver slices. This is in agreement with the work of ${ }^{[30]}$ who found that a reduction in the hepatic LC pool is the principle mechanism leading to impaired hepatic fatty acid metabolism.

In the present study, LC and insulin had the same effects on lipid metabolism in hemidiaphragm, adipose tissue, as well as, in liver slices, where both of them favor lipid storage as triacylglycerol (TAG). These effects may be located at the level of the receptor in the coupling between the receptor and the intracellular mediators resulting in the modulation of celluar lipid oxidation.

\section{Conclusion}

LC has no direct effect on basal glucose uptake or FFA release by peripheral tissues. It potentiates insulin-stimulated glucose uptake by adipose tissue and muscle tissue. It enhanced the suppressive effect of insulin on FFA release from different peripheral tissues.

\section{Acknowledgement}

Dr. Rasha Rizk Mansoura faculty of medicine, clinical pathology department is acknowledged for her contribution to the experimental part of the study.

\section{REFERENCES}

1. Leibovitz B, Mueller J. Carnitine. J Optimal Nutr.; 2: 90-109, 1993.

\section{Bernard A, Regault C, Mazue F, Le Borgne}

F, Demarquoy J. L-carnitine supplementation and physical exercise restore age-associated decline in some mitochondrial functions in the rat. $J$ Gerontol A Biol Sc Med Sci.; 63: 1027-1033, 2008.

\section{Kharatishvili I, Shan ZY, She DT, Foong S,} Kurniawan ND, Reutens DC. MRI changes and complement activation correlate with epileptogenicity in a mouse model of temporal lobe epilepsy. Brain Struct Funct.; 219(2): 683706, 2013.

\section{Malaguarnera M, Restuccia S, Di Fazio I,} Zoccolo AM, Ferlito L, Bentivegna P. Serum carnitine levels in chronic hepatitis $\mathrm{C}$ patients before and after lymphoblastoid interferon-alpha treatment. Biodrugs; 12: 65-69, 1999.

\section{Bellinghieri G, Santoro D, Calvani M,} Mallamace A, Savica V. Carnitine and hemodialysis. Am J Kidney Dis.; 41: S116-S122, 2003. 
6. Chatham JC, Forder JR. A 13C NMR study of glucose oxidation in the intact functioning rat heart following diabetes-induced cardiomyopathy. J Mol Cell Cardiol.; 10:1203-1213, 1993.

7. Jones LL, McDonald DA, Borum PR. Acylcarnitines: role in brain. Prog Lipid Res.; 49: 61-75, 2010.

8. Bell FP, Raymond TL, Patnode PL. The influence of diet and carnitine supplementation on plasma carnitine, cholesterol and triglyceride in WHHL (Watanabe Heritable Hyperlipidemic), Netherland Dwarf and New Zealand rabbits (Oryctolagus cuniculus). Comp Biochem Physiol.; 87: 587-591, 1987.

9. Maccari F, Arseni A, Chiodi P, Ramacci MT, Angelucci L, Hulsmann WC. L-carnitine effect on plasma lipoproteins of hyperlipidemic fatloaded rats. Lipids; 22: 1005-1008, 1987.

10. Feng Y, Guo C, Wei J, Yang J, Ge Y, Gao L. Necessity of carnitine supplementation in semistarved rats fed a high-fat diet. Nutr J.; 17: 628-631, 2001.

11. Hong YM, Kim HS, Yoon HR. Serum lipid and fatty acid profiles in adriamycin-treated rats after administration of L-carnitine. Pediatr Res.; 51: 249-255, 2002.

12. Rajasekar P, Anuradha CV. Effect of Lcarnitine on skeletal muscle lipids and oxidative stress in rats fed high-fructose diet. Exp Diabetes Res.; 1-8, 2007.

13. Stroedter D, Schmidt T, Bretzel RG, Federlin K. Glucose metabolism and left ventricular dysfunction are normalized by insulin and islet transplantation in mild diabetes in the rat. Acta Diabetol.; 32:235-243, 1995.

14. Llias I, Manoli I, Blackman MR, Gold PW, Alesci S. Lcarnitine and acetyl-L-carnitine in the treatment of complications associated with HIV infection and antiretroviral therapy. Mitochondrion; 4: 163-168, 2004.

15. Guarnieri G, Biolo G, Vinci P, Massolino B, Barazzoni R. Advances in carnitine in chronic uremia. J Ren Nutr.; 17: 23-29, 2007.

16. Cha YS. Effects of L-carnitine on obesity, diabetes, and as an ergogenic aid. Asia Pac J Clin Nutr.; 17: S306-S308, 2008.

17. Oshima M, Higashi S, Kikuchi $Y$, Fukumitsu M, Ban S, Shiai T, Furui S, Yasukoc. Auutoradiographic study of myocardial fatty acid metabolism in diabetic mouse using 1251-BMIPP. Mippon Igaku Hoskasen Gakkai Zasshi 1996, 56:137-138, 1996.

18. Mamoulakis D, Galanakis E, Dionyssopoulou E, Evangeliou A, Sbyrakis S. Carnitine deficiency in children and adolescents with type 1 diabetes. J Diabetes Comp.; 18: 271274, 2004.

19. AL-Majed A. Carnitine defeciency provokes cisplatin- induced hepatotoxicity in rats. Basic Clin Pharmacol Toxicol.; 100 (3): 145-150, 2007.

20. Coutrier A, Ringseis R, Moren F-C, Kruger K, Most E, Edler K. Carnitine supplementation to obeze Zucker rats prevents obesity - induced type II to type I muscle fiber transition and favors an oxidative phenotype of skeletal muscle. Nutr Metab.; 10:48-58, 2013.

21. Altun Z, Gunes D, Aktas S, Erbayrktar Z, Olgun N. Protective Effects of Acetyl-L-Carnitine on Cisplatin Cytotoxicity and Oxidative Stress in Neuroblastoma. Neurochem Res., 35:437-443, 2010.

22. Stephens FB, Constantin-Teodosiu D, Greenhaff PL. New insights concerning the role 
of carnitine in the regulation of fuel metabolism in skeletal muscle. J Physiol.; 581: 431-444, 2007.

\section{Poorabbas A, Fallah F, Bagdadchi J}

et al. Determination of free L-carnitine levels in type II diabetic women with and without complications. Eur J Clin Nutr.; 61:892-895, 2007.

24. Ringseis R, Keller J, Eder $\mathbf{K}$. Role of carnitine in the regulation of glucose homeostasis and insulin sensitivity: evidence from in vivo and in vitro studies with carnitine supplementation and carnitine deficiency . Eur J Nutr; 5: 1-18, 2012.

25. Bazotte RB and Lopes-Bertolini G. Effects of oral L-carnitine and DL-carnitine supplementation on alloxan-diabetic rats. Braz. Arch. Biol. Technol.; 55(1): 81-88, 2012.

26. Patel AD, Stanley SA, Murphy KG. Ghrelin stimulates insulin-induced glucose uptake in adipocytes. Regul Pept. ; 134(1): 17-22, 2006.

27. O'Brien RS, Streeper JE, Ayala BT Stadelmaier, Hornbuckle LA. Insulin-regulated gene expression. Biochem Soc Trans.; 29: 552$558,2001$.

28. Fritz IB. Carnitine and its role in fatty acid metabolism. Adv Lipid Res.; 1: 285-334, 1963.

29. Bieber LL. Carnitine. Annu Rev Biochem.; 57:261-283, 1988.

\section{Spaniol M, Kaufmann P, Beier K, Wüthrich}

\section{J, Török $\quad$ M, Scharnagl $\quad$ H, März}

W, Krähenbühl S. Mechanisms of liver steatosis in rats with systemic carnitine deficiency due to treatment with trimethyl-hydrazinium-propionate.

J. Lipid Res.; 44: (1) 144-153, 2003. 